\title{
ANALISIS KESALAHAN SISWA MADRASAH ALIYAH (MA) KELAS X DALAM MENYELESAIKAN SOAL TRIGONOMETRI
}

\author{
Siti Nur Asifa ${ }^{1}$, Luvy Sylviana Zanthy ${ }^{2}$ \\ ${ }^{, 1,2}$ Program Studi Pendidikan Matematika, IKIP Siliwangi \\ Email: stnurasifa02@gmail.com
}

\begin{abstract}
Abstrak:
Penelitian ini bertujuan untuk mendeskripsikan kesalahan siswa dalam menyelesaikan soal materi trigonometri. Jenis penelitian ini adalah deskriptif kualitatif. Subjek dalam penelitian ini adalah 10 siswa kelas X MAN 1 Cimahi. Populasi dari subjek penelitian dipilih secara acak berdasarkan kriteria yang sesuai dengan permasalahan penelitian. Pengumpulan data penelitian menggunakan metode tes dan wawancara. Dalam penelitian ini yang dimaksud dengan kesalahan siswa dalam menyelesaikan soal trigonometri adalah kemampuan siswa untuk menjawab tes soal trigonometri.Kemudian, dianalisis kesalahan hasil tes siswa untuk mengetahui seberapa banyak kesalahan yang dilakukan siswa. Analisis data yang digunakan mengacu pada analisis data menurut Miles dan Huberman yakni reduksi data, penyajian data, dan penarikan kesimpulan. Hasil penelitian menunjukan kesalahan yang dilakukan siswa yaitu kesalahan pengerjaan soal dalam operasi aljabar matematika serta kesalahan konsep dikarenakan siswa yang masih kurang paham materi trigonometri. Hal tersebut disebabkan siswa tidak teliti dan terburu-buru dalam mengerjakan soal dan siswa kurang menguasai konsep dasar operasi aljabar matematika.
\end{abstract}

Kata Kunci: Analisis, Kesalahan, Trigonometri

\section{Pendahuluan}

Menurut Peraturan Pemerintah Nomor 22 tahun 2006 (Khuzaini \& Santosa, 2016), Matematika merupakan ilmu universal yang mendasari perkembangan teknologi modern serta memiliki peran penting dalam meningkatkan daya pikir manusia. Menurut Depdiknas (Nursit, 2015), Matematika berfungsi mengembangkan kemampuan menghitung, mengukur, menurunkan dan menggunakan rumus matematika yang diperlukan dalam kehidupan sehari-hari melalui materi aljabar, geometri, logika matematika, peluang dan statistika. Menurut Zanthy (2016), Matematika merupakan salah satu pelajaran penting, karena selain dituntut kemampuan berfikir seseorang, banyak masalah dalam kehidupan yang dapat disajikan ke dalam model matematika. Dengan mempelajari matematika, siswa dapat terbiasa berfikir secara sistematis, ilmiah, menggunakan logika, kritis, serta dapat meningkatkan daya kreativitas siswa tersebut.

Mempelajari matematika tidak hanya bertujuan untuk mencerdaskan siswa, tetapi juga dapat membentuk kepribadian siswa untuk bersikap disiplin, tepat waktu, dan tanggung jawab. Menurut Farida(2015), matematika merupakan pelajaran yang sangat menakutkan bagi siswa hingga masih belum berubah sampai saat ini. Hal ini karena siswa banyak mengalami kesulitan dalam mempelajari matematika yang objek kajiannya abstrak. Menurut Muijs dan Reynalds (Khuzaini \& Santosa, 2016), Matematika merupakan salah satu mata pelajaran yang sulit dan menyebabkan siswa mengalami kesulitan untuk memahami materi pelajaran matematika yang abstrak. Menurut Sousa (Khuzaini \& Santosa, 2016), Kesulitan siswa mempelajari matematika juga disebabkan oleh sifatnya yang abstrak dan membutuhkan kemampuan berpikir logis serta terurut. Oleh karena itu, sebagian besar siswa tidak cukup tertarik dan yakin mampu mempelajari matematika dengan baik.

Menurut Cooney \& Cotton (Wahyuni, 2017), beberapa siswa memandang matematika sebagai hal yang menarik dan sebagian lagi memandang bahwa matematika adalah hal yang membosankan. Bahkan menurut Hoyles 
(Wahyuni, 2017), beberapa siswa memandang matematikasebagai subjek yang menyebabkan ketakutan, kecemasan dan kemarahanselama pembelajaran. Matematika selalu identik dengan konsep dan siswa akan selalu dituntut untuk bisa memahami konsep-konsep yang ada pada matematika. Cucu (Andriani, Suastika, \& Sesanti, 2017), menyatakan bahwa konsep adalah ide atau gagasan yang dibentuk dengan memandang sifat-sifat yang sama dari sekumpulan eksemplar yang cocok.

Penguasaan konsep dalam matematika diperlukan untuk memecahkan masalah dalam matematikasebagai wujud aplikasi dari konsep tersebut. Menurut Andriani dkk., (2017), Kesalahan yang lebih sering terjadi pada siswa saat mengerjakan soal adalah kesalahan pada konsep atau biasa disebut miskonsepsi. Konsep awal yang tidak dapat diterima siswa dengan baik dapat mengakibatkan miskonsepsi yang berlanjut. Jika miskonsepsi siswa tidak segera ditangani maka akan membuat siswa kesulitan dalam belajar dan berakhir pada rendahnya prestasi belajar siswa. Hal ini sejalan dengan pendapat Rahmawati , Priatna, \& Nurjanah(2018), bahwa dalam proses pembelajaran terlihat siswa terlihat masih sulit menghubungkan materi yang mereka pelajari dengan materi prasyarat yang sudah mereka kuasai, siswa tidak dapat mengingat konsep-konsep yang telah dipelajari.

MenurutYulandari (Huljannah dkk., 2015), Trigonometri adalah materi yang dianggap sulit oleh sebagian besar siswa dalam mata pelajaran matematika sehingga siswa sering mengalami kebingungan dalam menerapkannya. Dalam pembelajaran di kelas seringkali dijumpai beberapa siswa yang mengalami kesulitan belajar termasuk pada materi trigonometri yang disebabkan oleh ketidakpahaman siswa terhadap konsep matematika. Menurut Nurcikawati, dkk, (2018), trigonometri merupakan salah satu materi yang di ujikan dalam Ujian Nasional (UN) dan materi matematika yang dianggap sulit oleh sebagian siswa karena materi trigonometri merupakan salah satu materi dalam matematika yang bersifat abstrak sekaligus materi yang memiliki tingkat kesulitan tersendiri. Anggapan siswa bahwa matematika merupakan mata pelajaran yang sulit dapat menjadi alas an timbulnya siswa banyak melakukan kesalahan dalam mengerjakan soal matematika.

BerdasarkanBrown \& Skow (Rahmania \& Rahmawati, 2016), mengatakan bahwa analisis kesalahan telah terbukti menjadi metode yang efektif untuk mengidentifikasi pola dari kesalahan matematis siswa. Menurut Rahmania \& Rahmawati (2016), analisis kesalahan sangatlah penting dan perlu terus dikembangkan agar para pengajar dapat mengetahui kesalahan-kesalahan yang biasa dilakukan oleh siswanya sehingga pengajar dapat mengidentifikasi dan meninjau kesalahan yang sering dilakukan oleh siswa. Dengan dilakukan analisis kesalahan, pengajar dapat memilih strategi yang tepat agar siswa tidak melakukan kesalahan lagi.

Terkait dengan hal itu peneliti melakukan wawancara dengan guru matematika kelas $\mathrm{X}$ MAN Cimahi dan diperoleh informasi bahwa materi matematika yang dianggap sulit oleh siswa adalah trigonometri. Akibatnya siswa sering melakukan kesalahan dalam menyelesaikan soal. Jika keadaan ini terus terjadi maka besar kemungkinan kesalahan lainnya akan terjadi yang pada akhirnya menyebabkan rendahnya hasil belajar siswa. Oleh karena itu, peneliti akan melakukan analisis kesalahan siswa dalam menyelesaikan soal trigonometri.

\section{Metode Penelitian}

Jenis penelitian ini adalah penelitian deskriptif kualitatif. Subjek penelitian ini adalah siswa kelas $\mathrm{X}$ MAN Cimahi sebanyak 10 siswa. Pemilihan subjek berdasarkan beberapa pertimbangan, yaitu: (1) siswa yang paling banyak melakukan kesalahan dalam mengerjakan soal matematika khususnya pada materi trigonometri, (2) siswa bersedia menjadi subjek pada penelitian ini, dan (3) siswa mampu berkomunikasi dan mengungkapkan pendapat dengan baik.

Teknik pengumpulan data pada penelitian ini adalah tes dan wawancara. Data yang diperoleh dengantes adalah 
kesalahan yang dilakukan siswa. Data yang diperoleh dengan wawancara adalah jenis dan letak kesalahan yang dilakukan siswa serta penyebab terjadinya kesalahan yang dilakukan oleh siswa. Dalam penelitian ini yang dimaksud dengan kesalahan siswa dalam menyelesaikan soal trigonometri adalah kemampuan siswa untuk menjawab tes soal trigonometri. Tes soal trigonometri menggunakan soal-soal terkait dengan materi yang sudah dipelajari siswa yang berjumlah 5 soal. Soal yang diujikan merupakansoal yang sudah diuji validitas. Setelah intrumen diujikan kepada siswa, kemudian akan dianalisis kesalahan hasil tes siswa untuk mengetahuikesalahan yang dilakukan siswa.

Teknik pemeriksaan keabsahan data yang digunakan adalah triangulasi metode. Triangulasi metode dilakukan dengan membandingkan data hasil tes dan data hasil wawancara. Analisis data yang digunakan mengacu pada analisis data menurut Miles dan Huberman (Zain, Supardi, \& Lanya, 2017:14), yaitu data reduction (Reduksi Data), data display (Penyajian Data), dan conclusion drawing/verification (Penarikan Kesimpulan).

Tabel 1. Instrumen Tes Trigonometri

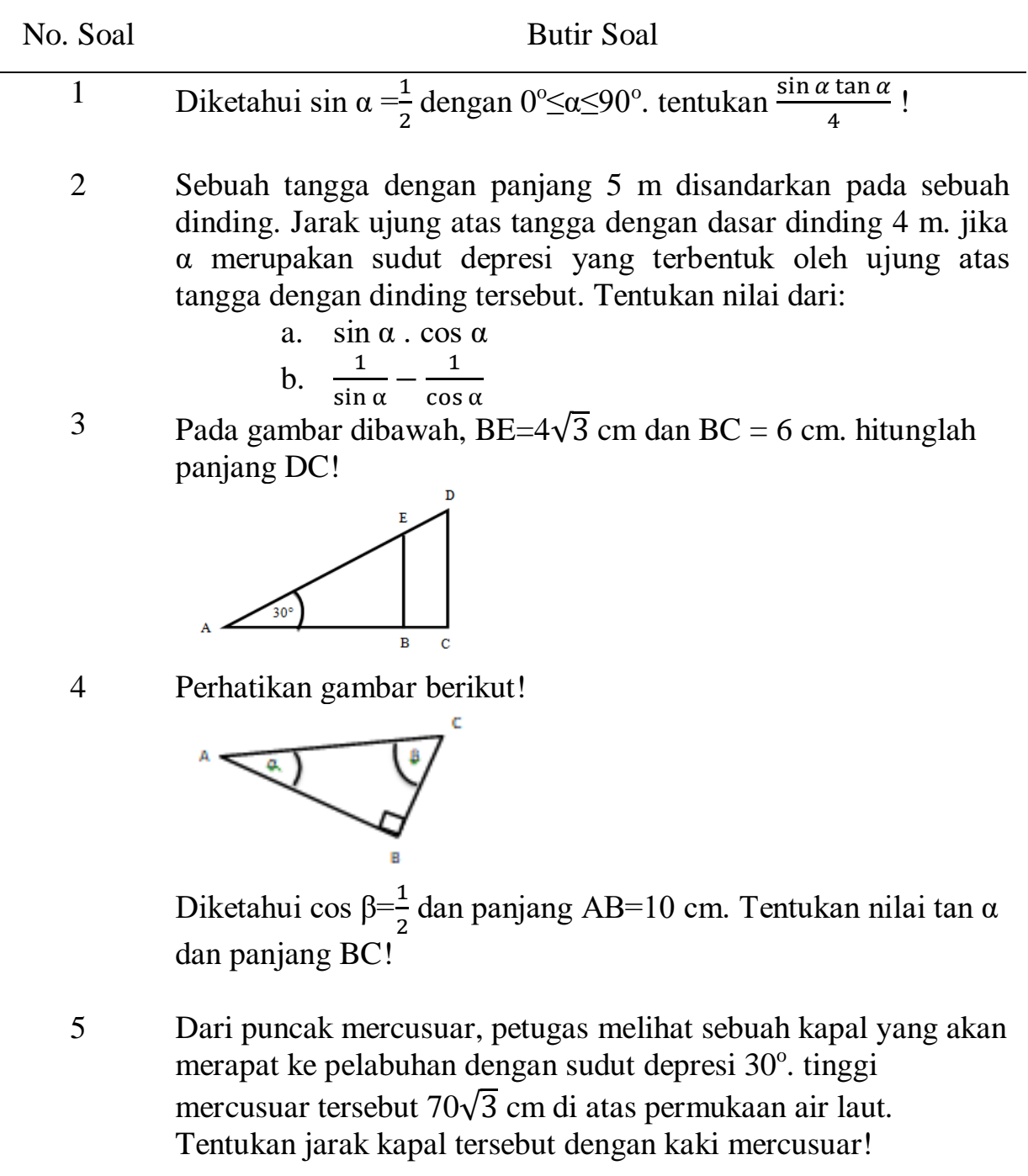

\section{Hasil dan Pembahasan}

Peneliti memberikan tes kepada 10 siswa kelas $X$ mengenai materi pembelajaran trigonometri. Tes yang diberikan terdiri dari 5 butir soal. Kemudian dipilih soal yang paling banyak kesalahan 
dalam pengerjaan soal dengan persentase kecil. Untuk lebih mengetahui faktor yang membuat siswa melakukan kesalahan peneliti melakukan wawancara kepada 10 siswa.

\section{Tabel 2. Persentase Kesalahan Siswa dalam Menjawab Soal Trigonometri}

\begin{tabular}{|c|c|c|c|}
\hline \multirow{2}{*}{$\begin{array}{l}\text { No. } \\
\text { Soal }\end{array}$} & \multirow[t]{2}{*}{ Indikator } & \multicolumn{2}{|c|}{$\begin{array}{c}\text { Persentase subjek menjawab soal } \\
\text { dengan benar }\end{array}$} \\
\hline & & Jumlah subjek & persentase \\
\hline 1 & $\begin{array}{l}\text { Menghitung nilai hasil perkalian sinus dan } \\
\text { tangen suatu sudut lancip yang dibagi suatu } \\
\text { bilangan apabila nilai sinus sudut tersebut } \\
\text { diketahui. }\end{array}$ & 1 & $10 \%$ \\
\hline 2 & $\begin{array}{l}\text { Menghitung nilai hasil perkalian dan } \\
\text { penjumlahan sinus dan tangen suatu sudut } \\
\text { yang terbentuk oleh sebuah tangga dan } \\
\text { dinding apabila panjang tangga dan tinggi } \\
\text { dinding diketahui. }\end{array}$ & 9 & $90 \%$ \\
\hline 3 & $\begin{array}{l}\text { Menghitung tinggi suatu segitiga apabila } \\
\text { salah satu sudut dan panjang alas segitiga lain } \\
\text { yang besar sudutnya sama diketahui. }\end{array}$ & 1 & $10 \%$ \\
\hline 4 & $\begin{array}{l}\text { Menghitung nilai tangen suatu sudut lancip } \\
\text { dan panjang salah satu sisi pada segitiga siku- } \\
\text { siku apabila nilai cosinus suatu sudut lancip } \\
\text { dan panjang salah satu sisi yang lain } \\
\text { diketahui. }\end{array}$ & 7 & $70 \%$ \\
\hline 5 & $\begin{array}{l}\text { Menghitung jarak kapal ke mercusuar apabila } \\
\text { sudut depresi dan tinggi mercusuar diketahui. }\end{array}$ & 1 & $10 \%$ \\
\hline
\end{tabular}

Berdasarkan tabel hasil penelitian di atas, dapat dilihat bahwa terdapat tiga soal yang memiliki persentase rendah yaitu $10 \%$ yaitu soal nomor 1 , nomor 3 , dan nomor 5. Peneliti melakukan wawancara pada 3 subjek untuk mengetahui dengan jelas mengenai faktor yang membuat terjadinya kesalahan dalam pengerjaan soal.

\section{Jawaban tertulis dan wawancara subjek 1 pada nomor 1}

Soal nomor 1 yang diberikan adalah sebagai berikut:

Diketahui $\sin \alpha=\frac{1}{2}$ dengan $0^{\circ} \leq \alpha \leq 90^{\circ}$.

Tentukan $\frac{\sin \alpha \tan \alpha}{4}$ !

Adapun jawaban subjek pada soal nomor 1 dipaparkan sebagaimana Gambar 1:

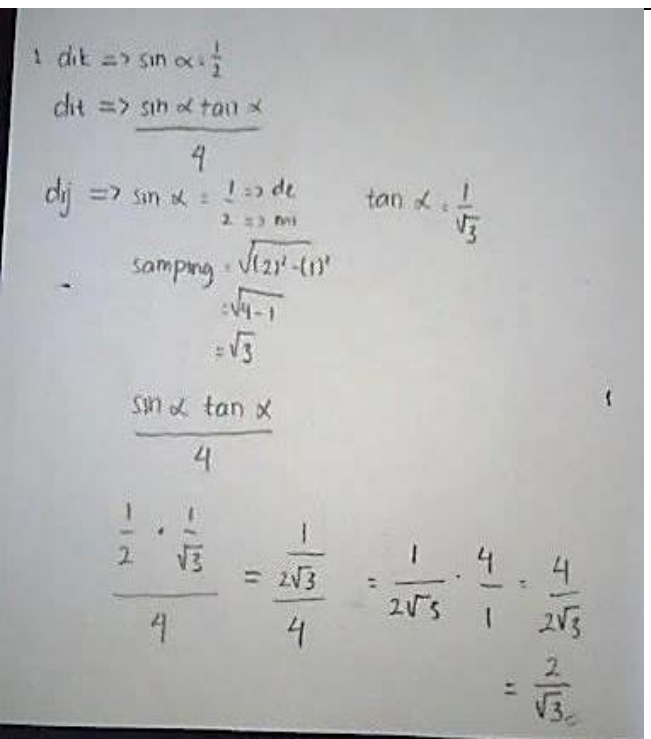

Gambar 1. Jawaban Subjek Nomor 1

\section{Analisis Kesalahan}

Berdasarkan Gambar 1, subjek 1 untuk soal nomor 1 melakukan kesalahan pada proses pengoperasian bentuk pecahan sehingga subjek tidak mendapatkan 
jawaban yang tepat. Subjek sudah benar dalam menuliskan apa yang diketahui dan apa yang ditanyakan dalam soal. Subjek juga berhasil memakai rumus yang tepat untuk menyelesaikan soal. Tetapi, pada saat pengoprasian dalam bentuk pecahan subjek mengalami kesalahan. Akibatnya, subjek mendapatkan hasil yang salah. Hal ini sejalan dengan hasil penelitian Huljannah dkk., (2015) bahwa siswa salah dalam mengoperasi aljabar bentuk pecahan yang disebabkan oleh ketidakpahaman subjek mengenai prinsip operasi pada aljabar bentuk pecahan.

\section{Wawancara}

P: “ Nak, jawabannya sudah benar, tapi ini pengerjaan bentuk pecahannya kurang tepat."

$\mathrm{S}$ : "iya $\mathrm{Bu}$, Saya lupa lagi caranya. Itu kan ada akarnya"

P: "coba perhatikan kembali perhitungan nya"

S: "iya Bu, saya coba kembali."

Berdasarkan wawancara di atas, dapat diketahui bahwa subjek mengalami kesalahan dalam menjawab soal nomor 1 karena tidak dapat mengingat cara yang tepat untuk menjalakan perhitungan bentuk pecahan yang tepat. Meskipun subjek sudah mengerti bagaimana cara untuk menyelesaikan soal, namun karena subjek melakukan kesalahan dalam perhitungan sehingga hasil nya juga salah.

\section{Jawaban tertulis dan wawancara subjek 2 pada nomor 3}

Soal nomor 3 yang diberikan adalah sebagai berikut:

Pada gambar dibawah, $\mathrm{BE}=4 \sqrt{3} \mathrm{~cm}$ dan $\mathrm{BC}=6 \mathrm{~cm}$. Hitunglah panjang DC!

A

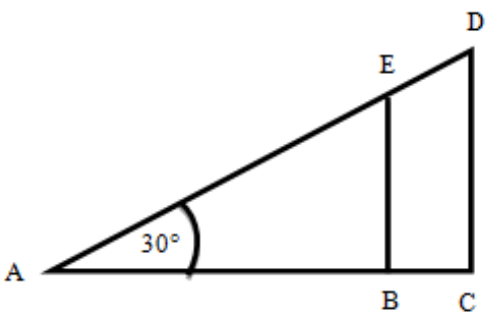

Adapun jawaban subjek pada soal nomor 3 dipaparkan sebagaimana Gambar 2:

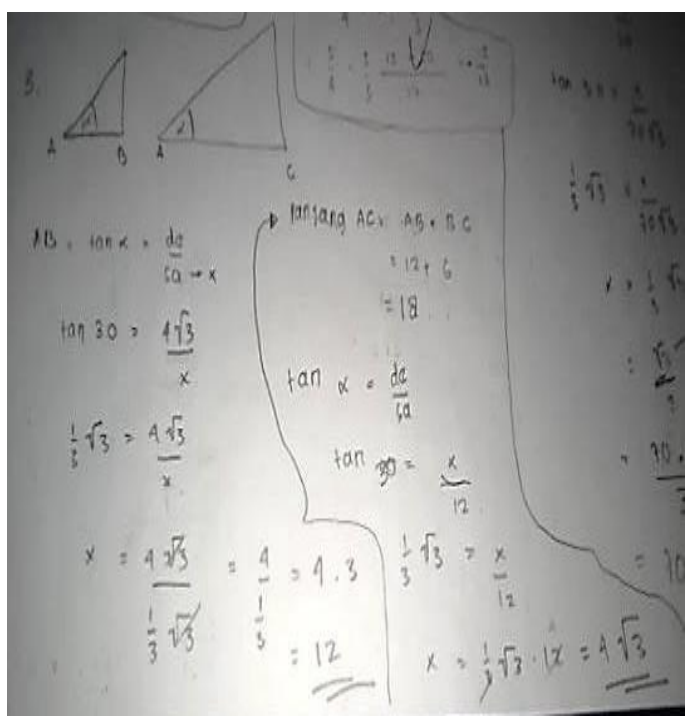

Gambar 2. Jawaban Subjek Nomor 3

\section{Analisis Kesalahan}

Berdasarkan Gambar 2, subjek 2 melakukan kesalahan pada konsep materi trigonometri sehingga subjek tidak mendapatkan jawaban yang tepat. Subjek sudah benar dalam melakukan perhitungan operasi untuk menyelesaikan soal. Tetapi, terjadi misconsepsi sehingga subjek keliru dalam menentukan sumber yang telah diketahui untuk dipakai dalam menyelesaikan soal. Sejalan dengan hasil penelitian Andriani dkk., (2017) bahwa, siswa banyak yang salah dalam memaparkan konsep bahkan ada yang tidak memaparkan konsep sama sekali.

\section{Wawancara}

P: "Nak, coba kamu perhatikan soal, apa yang ditanyakan dalam soal?"

S: "Panjang DC Bu."

P: "Coba bagaimana cara mencari DC?"

S: "Menghitung nilai AB segitiga ABE."

P: "Coba perhatikan apa kamu sudah tepat menghitung nilai DC?" 
$\mathrm{S}$ : "Saya salah memasukan nilai $\mathrm{Bu}$, seharus nya 18 karena panajang $\mathrm{AB}+\mathrm{BC}=12+6=18 . "$

P: "Kamu benar, kenapa bias salah, nak?"

S: "Saya tidak teliti, Bu."

Berdasarkan wawancara diatas, dapat diketahui bahwa penyebab subjek mengalami kesalahan dalam menjawab soal nomor 3 adalah kesalahan pada konsep materi trigonometri. Subjek tidak teliti dalam menggunakan informasi yang didapat, sehingga tidak mendapatkan hasil yang tepat. Subjek melakukan kekeliruan dalam memilih dan menentukan sumber yang sudah diketahui. Akibatnya, subjek mendapatkan hasil yang salah dalam menyelesaikansoal trigonometri.

\section{Jawaban tertulis dan wawancara subjek 3 pada nomor 5}

Soal nomor 5 yang diberikan adalah sebagai berikut:

Dari puncak mercusuar, petugas melihat sebuah kapal yang akan merapat ke pelabuhan dengan sudut depresi $30^{\circ}$. Tinggi mercusuar tersebut $70 \sqrt{3} \mathrm{~cm}$ di atas permukaan air laut. Tentukan jarak kapal tersebut dengan kaki mercusuar!

Adapun jawaban subjek 3 pada soal nomor 5 dipaparkan sebagaimana Gambar 3:

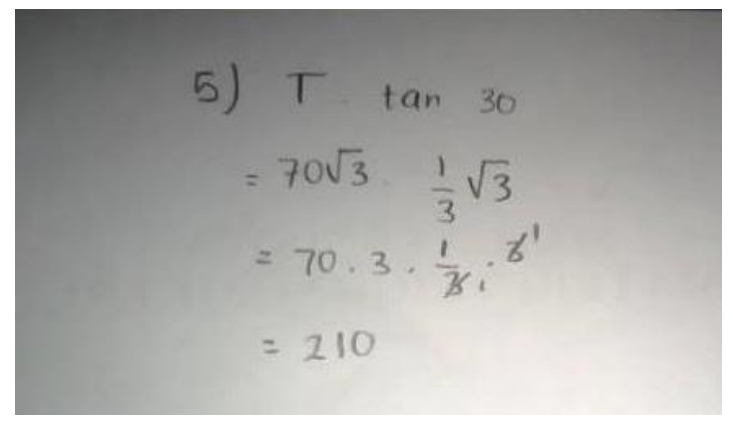

Gambar 3. Jawaban Subjek Nomor 5

\section{Analisis Kesalahan}

Berdasarkan Gambar 3, subjek 3 melakukan kesalahan untuk nomor 5 pada proses perhitungan sehingga subjek tidak mendapatkan jawaban yang tepat. Subjek tidak menuliskan apa yang diketahui dan ditanyakan dalam soal. Subjek mengalami kesalahan dalam perhitungan perkalian akar. Subjek menuliskan $(70 \times 3) \times(1 / 3 \times 3)$ disini terjadi kesalahan. Seharus nya subjek hanya menulisakan perkalian $\sqrt{3}$ hanya satu kali. Sehingga subjek akan menemukan hasil $70 \times 3 \times 1 / 3=70$. Sejalan dengan hasil penelitian Huljannah dkk., (2015) mengatakan, salah dalam melakukan operasi aljabar dan akar kuadrat, hal ini disebabkan oleh kurangnya pemahaman subjek mengenai prinsip operasi aljabar dan akar kuadrat.

\section{Wawancara}

P: “ Nak, kenapa tidak menuliskan apa yang diketahui dan ditanyakan di dalam soal?

S: "Saya buru-buru, Bu"

P: "Kamu mengerti permasalahan yang di maksud dalam soal?"

S: "Mencari jarak kapal dengan mercusuar, $\mathrm{Bu}$. Yang diketahuinya sudut depresi $30^{\circ}$ dan tinggi mercusuar tersebut $70 \sqrt{3}$."

P: "Berapa nilai dari tan $30^{\circ}$ ?"

S: " $1 / 3 \sqrt{3}$, Bu."

P: "Nak, $\sqrt{3} \times \sqrt{3}$ berapa?"

S: “3, Bu?”

P: "Kenapa menulis nya 2 kali?"

S: "Saya tidak tahu Bu. Kan akar nya hilang jadi tinggal 3 saja."

P: "Benar, kamu tidak perlu menulisnya 2 kali, cukup 1 aja."

S: "Baik bu, saya lupa lagi caranya."

Berdasarkan wawancara di atas, diketahui bahwa penyebab subjek melakukan kesalahan dalam menjawab soal nomor 5 adalah tidak ingat bagaimana aturan perkalian pada akar. Subjek juga tidak memperhatikan dengan cermat apa yang diketahui dalam soal. Meskipun subjek sudah mengerti cara menyelesaikan soal nya namun karena dalam perhitungan salah sehingga hasil nya juga salah. 


\section{Simpulan dan Saran}

Berdasarkan hasil penelitian dan pembahasan diperoleh kesimpulan,antara lain: 1) Siswa mengalami banyak kesalahan pada operasi aljabar matematika. Sehingga siswa mengalami kesalahan dalam perhitungan karena terburu-buru dan kurang teliti dalam melakukan perhitungan.2) Masih terdapat siswa yang belum paham mengenai konsep dari materi trigonometri, sehingga mereka kesusahan dalam menentukan rumus yang akan digunakan.

Kesalahan pada operasi aljabar matematika yang dilakukan siswa cenderung pada perhitungan pecahan serta bentuk akar. Pada dasarnya siswa kurang menguasai konsep dasar matematika, sehingga terjadi kekeliruan dalam mengerjakan soal pada bagian operasi aljabar matematika.

Berdasarkan pembahasan dan kesimpulan yang didapat, maka saran dari peneliti yaitu: 1) Hasil penelitian dan temuannya dapat dijadikan pijakan untuk penelitian lanjutan oleh peneliti lain sebagai wacana tentang analisis kesalahan yang dilakukan siswa dalam mengerjakan soal matematika khususnya pada materi trigonometri. 2) Hasil penelitian dan temuannya dapat dijadikan sebagai informasi bagi guru matematika untuk bisa lebih banyak memberikan penanaman konsep dan memperbanyak latihan soal matematika khususnya materi trigonometri sehingga dapat mengurangi atau paling tidak meminimalisasi terjadinya kesalahan yang terjadi pada siswa dalam menyelesaikan soal matematika.

\section{Daftar Pustaka}

Andriani, T., Suastika, I. K., \& Sesanti, N. R. (2017). Analisis Kesalahan Konsep Matematika Siswa dalam Menyelesaikan Soal Trigonometri Kelas X TKJ SMKN 1 Gempol Tahun Pelajaran 2016/2017. Pi: Mathematics Education Journal, 1(1), 34-39.

Farida, N. (2015). Analisis Kesalahan Siswa SMP Kelas VIII Dalam Menyelesaikan Masalah Soal Cerita
Matematika. Aksioma, 151(2), 42-52.

Huljannah, M., Sugita, G., \& Anggraini. (2015). Analisis Kesalahan Siswa dalam Menyelesaikan Soal Persamaan dan Identitas Trigonometri Berdasarkan Kriteria Watson di Kelas X SMA Al-Azhar Palu. Jurnal Pendidikan Matematika, 4(2), 164-176.

Khuzaini, N., \& Santosa, R. H. (2016). Pengembangan Multimedia Pembelajaran Trigonometri Menggunakan Adobe Flash Cs3 Untuk Siswa SMA. Jurnal Riset Pendidikan Matematika, 3(1), 88.

Nurcikawati, Agustian, Y., Apipah S., E., \& Casnan. (2018). Rancang Bangun Media Pembelajaran Trigonometri Berbasis Multimedia Interaktif.SOSIOHUMANIORA: Jurnal Ilmiah Ilmu Sosial dan Humaniora, 4(2), 114-121.

Nursit, I. (2015). Metode Discovery Berdasarkan Teori Beban Kognitif. Jurnal Pendidikan Matematika, I, 4252.

Rahmania, L., \& Rahmawati, A. (2016). Analisis Kesalahan Siswa dalam Menyelesaikan Soal Cerita Persamaan Linier Satu Variabel. JMPM: Jurnal Matematika dan Pendidikan Matematika, l(2), 165.

Rahmawati Z, Y., Priatna, N., \& Nurjanah. (2018). Meningkatkan Kemampuan Koneksi Matematis Dan Self-Concept Siswa Melalui Pendekatan Sainstifik Pada Materi Trigonometri. 3(2), 108122.

Sultoni, A. (2018). Pembelajaran Trigonometri Materi Menentukan Tinggi Suatu Benda Berbantuan Klinometer Fleksibel. 1, 860-869.

Wahyuni, A. (2017). Analisis Hambatan Belajar Mahasiswa Pada Mata Kuliah Kalkulus Dasar.JNPM (Jurnal Nasional Pendidikan Matematika), 1(1), 10.

Zain, A. N., Supardi, L., \& Lanya, H. 
56|SIGMA, Volume 5, Nomor 2, Maret 2020, HIm 49-56

(2017). Analisis Kesalahan Siswa dalam Menyelesaikan Materi Trigonometri Kelas X.Sigma, 3(1), 12-16. Retrieved from

Zanthy, L. S. (2016). Pengaruh Motivasi
Belajar Ditinjau dari Latar Belakang

Pilihan Jurusan Terhadap

Kemampuan Berpikir Kritis

Mahasiswa di STKIP Siliwangi

Bandung. 1(1). 